\title{
Development of TaqMan ${ }^{\circledR}$ MGB fluorescent real-time PCR assay for the detection of anatid herpesvirus I Yufei Guo 1,2, Anchun Cheng*1,2, Mingshu Wang*1,2, Chanjuan Shen², Renyong Jia ${ }^{1}$, Shun Chen ${ }^{1}$ and Na Zhang ${ }^{1}$
}

\author{
Address: ${ }^{1}$ Avian Disease Research Center, College of Veterinary Medicine, Sichuan Agricultural University, Yaan 625014, PR China and ${ }^{2}$ Key \\ Laboratory of Animal Diseases and Human Health of Sichuan Province, Sichuan Agricultural University, Yaan 625014, PR China \\ Email: Yufei Guo - gyf02@163.com; Anchun Cheng* - chenganchun@vip.163.com; Mingshu Wang* - mshwang@163.com; \\ Chanjuan Shen - vober@163.com; Renyong Jia - cqrc_jry@163.com; Shun Chen - sophia_cs@163.com; Na Zhang - nana821024@sohu.com \\ * Corresponding authors
}

Published: 4 June 2009

Virology Journal 2009, 6:71 doi:10.1186/1743-422X-6-71

This article is available from: http://www.virologyj.com/content/6/I/7I

(c) 2009 Guo et al; licensee BioMed Central Ltd.

This is an Open Access article distributed under the terms of the Creative Commons Attribution License (http://creativecommons.org/licenses/by/2.0), which permits unrestricted use, distribution, and reproduction in any medium, provided the original work is properly cited.
Received: 6 April 2009

Accepted: 4 June 2009

\begin{abstract}
Background: Anatid herpesvirus I (AHV-I) is an alphaherpesvirus associated with latent infection and mortality in ducks and geese and is currently affecting the world-wide waterfowl production severely. Here we describe a fluorescent quantitative real-time PCR (FQ-PCR) method developed for fast measurement of AHV-I DNA based on TaqMan MGB technology.

Results: The detection limit of the assay was $1 \times 10^{\prime}$ standard DNA copies, with a sensitivity of 2 logs higher than that of the conventional gel-based PCR assay targeting the same gene. The realtime PCR was reproducible, as shown by satisfactory low intra-assay and inter-assay coefficients of variation.

Conclusion: The high sensitivity, specificity, simplicity and reproducibility of the AHV-I fluorogenic PCR assay, combined with its wide dynamic range and high throughput, make this method suitable for a broad spectrum of AHV-I etiologically related application.
\end{abstract}

\section{Background}

China is currently holding the largest waterfowl population in the world and its waterfowl production industry has been characterized by an increasing expansion and rapid development during the past decades [1]. However, infectious diseases represent the biggest obstacle to successful development of this business. Anatid herpesvirus 1 (AHV-1) infection alternatively known as duck virus enteritis (DVE), or duck plague (DP) [2], is one of the most widespread and devastating diseases of waterfowls in the family Anatidae and has severally affected the waterfowl industry since the early 1900 s because relatively high mortality could be observed and a wide host range including domestic [3] and wild ducks [4,5], geese and swans of all species as well as other birds like coots are susceptible. Furthermore, serious carcass condemnations and decreased egg production were also observed in affected waterfowls. Like other herpesvirus-induced diseases, AHV-1 infection has latent form and the virus can be persistently shed by birds that recover from the disease [6]. This complicates the control of the disease, particularly under small-holder farming conditions prevalent in China.

The causative agent of AHV-1 is grouped in the alphaherpesviridae subfamily of the herpesvirus family [7] and the 
viral genome is a linear, double-stranded DNA molecule approximately $180 \mathrm{~kb}$ in size and its structure is similar to other alphaherpesviruses [8]. The AHV-1 genomic DNA has $\% \mathrm{G}+\mathrm{C}$ content of 64.3 , which is the highest reported for any avian herpesvirus in the alphaherpesviridae [9].

Since prevention and early detection are presently the most logical strategies for virus control, various diagnostic procedures including microscopic, immunological and molecular methods have been developed for AHV-1 detection, of which the polymerase chain reaction (PCR) is a powerful tool with exquisite sensitivity for detection of minute amounts of nucleic acids, even against a high background of unrelated nucleic acids. Fluorescent quantitative real-time PCR (FQ-PCR) technique has eliminated the need of sample post-amplification handling required by the conventional PCR assay and has paved the way towards fully automated detection systems now that they usually display very high sensitivity and broad dynamic capacity after optimization [10-12]. Since virus load and proliferation dynamics serve as indispensable indicators of virus-host interaction, antiviral evaluation, active/ latent infection [13-15] and guidance for therapeutic intervention, FQ-PCR is therefore of paramount importance by its exquisite virus detection and monitoring ability [16].

The detection of AHV-1 by TaqMan real-time PCR method has only been reported by Yang [17] and with the development of technology, TaqMan Minor Groove Binding $\left(\mathrm{MGB}^{\mathrm{TM}}\right)$ probes as an upgrade of the ordinary TaqMan probe has been widely used during the recent years since the following advantages: (1) The TaqMan MGB probe is characterized by the conjugation of minor groove binders which facilitates highly specific of the detection. (2) The TaqMan MGB probe contains a quencher dye that does not emit fluorescence within the detectable wavelength range and results in greater accuracy in the measurement. Therefore a TaqMan MGB-based real-time PCR method for detection and quantitation of AHV-1 is developed to serve as an alternative and improvement of the previously developed ordinary TaqMan real-time PCR method.

\section{Results \\ Development and optimization of FQ-PCR and conventional PCR}

Following the optimization of FQ-PCR, final concentrations of primers each of $0.3 \mu \mathrm{mol} / \mathrm{L}$ and probe of 0.1 $\mu \mathrm{mol} / \mathrm{L}$ were selected. The $\mathrm{MgCl}_{2}$ concentration was balanced to $6 \mathrm{mM}$ that provided optimal AHV-1 amplification. Therefore the optimized $25-\mu \mathrm{L}$ real-time PCR reaction system for AHV-1 detection could be summarized as follows: $1 \times$ PCR buffer, $6 \mathrm{mmol} / \mathrm{L} \mathrm{MgCl}_{2}, 0.2$ $\mathrm{mmol} / \mathrm{L}$ dNTPs, $0.3 \mu \mathrm{mol} / \mathrm{L}$ each primers, $0.1 \mu \mathrm{mol} / \mathrm{L}$ probe, $1 \mathrm{U}$ Taq and $1 \mu \mathrm{L}$ DNA template.
Following the optimization of conventional PCR, the $\mathrm{MgCl}_{2}$ concentration was balanced to $2.5 \mathrm{mM}$ and the annealing temperature of $52^{\circ} \mathrm{C}$ was selected. Therefore the optimized conventional PCR reaction system could be summarized as follows: $1 \times$ PCR buffer, $2.5 \mathrm{mmol} / \mathrm{L}$ $\mathrm{MgCl}_{2}, 0.2 \mathrm{mmol} / \mathrm{L} \mathrm{dNTPs}, 0.5 \mu \mathrm{mol} / \mathrm{L}$ each primers, 1.25 $\mathrm{U}$ Taq and $1 \mu \mathrm{L}$ DNA template. The optimized annealing temperature was $52^{\circ} \mathrm{C}$.

\section{Fluorescent quantitative real-time PCR standard curve establishment}

The FQ-PCR amplification curves and the corresponding fluorescent quantitative real-time PCR standard curve (Figure 1) were generated by employing the successively diluted known copy number of pAHV-1 for real-time PCR reaction under the optimized conditions. From the results of correlation coefficient (0.999) and PCR efficiency $(86.9 \%)$ of the standard curve by the established FQ-PCR, it could be known that the standard curve and the established FQ-PCR are excellent at performance.

\section{Sensitivity, specificity, reproducibility and dynamic range of the established FQ-PCR}

Different 32 AHV-1 strains kindly provided by the Avian Disease Research Center of Sichuan Agricultural University were examined with the established FQ-PCR method and these specimens all tested positive in the FQ-PCR assay, indicating that this method is sensitive and compatible with wide range of AHV-1 viruses. Ten-fold dilution series of pAHV-1 plasmid standard DNA were tested by the established real-time PCR assay to evaluate the sensitivity of the system and the detection limit was found to be $1.0 \times 10^{1}$ copies/reaction. Comparisons were made between conventional PCR and the established FQ-PCR using dilution series to calculate the end point sensitivity of each assay. The results indicate that the established FQPCR is around 100 times more sensitive than the conventional PCR method, detecting pAHV-1 down to dilutions of $1.0 \times 10^{1}$, compared to dilutions of only $1.0 \times 10^{3}$ for conventional PCR.

The test using DNA from several other bacteria and viruses used as template to examine the technique's specificity showed that none of the bacteria, virus (other than AHV1 ) and duck embryo fibroblast tested gave any amplification signal and the results demonstrated that the established FQ-PCR assay is of highly specific.

The intra-assay and inter-assay CV of this established FQPCR was in the range of $1-3 \%$ for most of the dynamic range (from $1.0 \times 10^{9}$ to $1.0 \times 10^{2} \mathrm{pAHV}-1$ plasmid copies/ $\mu \mathrm{L})$, but increased to more than $6 \%$ at viral DNA loads lower than $1.0 \times 10^{2} \mathrm{pAHV}-1$ plasmid copies $/ \mu \mathrm{L}$ and increased to more than $4 \%$ at viral DNA loads more than $1.0 \times 10^{9} \mathrm{pAHV}-1$ plasmid copies $/ \mu \mathrm{L}$ (Table 1 ). The results 


\section{Correlstion Coefficient: 0.999 Slope: -3.681 Intercept: $46.645 Y=-3.681 X+46.645$ PCR Effioency: $8.9 \%$}

\section{- Unknowns \\ - Standards}

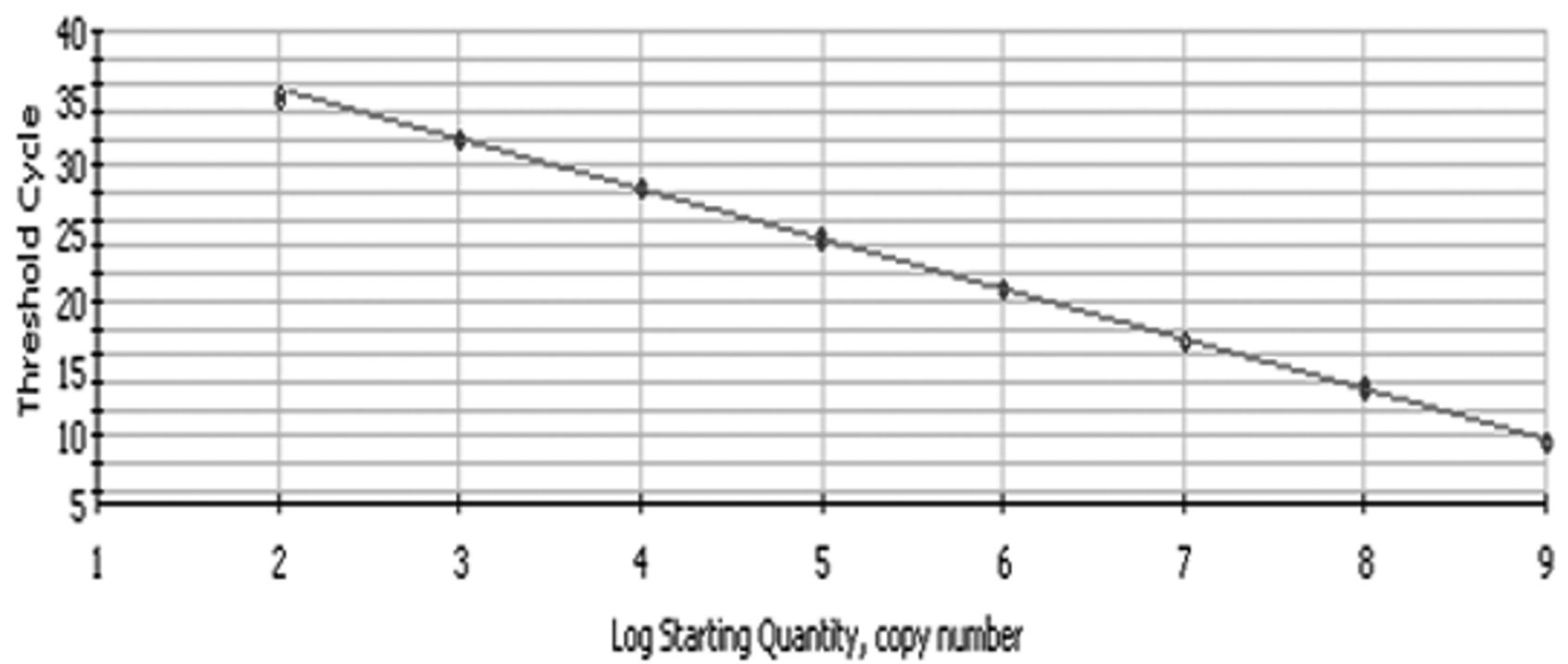

Figure I

Establishment of the fluorescent quantitative real-time PCR standard curve. Standard curve of the AHV-I fluorescent quantitative real-time PCR. Ten-fold dilutions of standard DNA ranging from $1.0 \times 10^{9}$ to $1.0 \times 10^{2} \mathrm{copies} / \mu \mathrm{L}$ were used, as indicated in the $x$-axis, whereas the corresponding cycle threshold (CT) values are presented on the $y$-axis. Each dot represents the result of triplicate amplification of each dilution. The correlation coefficient and the slope value of the regression curve were calculated and are indicated.

Table I: Intra- and inter-assay variability of the established FQ-PCR assay

\begin{tabular}{|c|c|c|c|c|c|c|}
\hline \multirow[t]{2}{*}{ Dilution of standard (copies/reaction) } & \multicolumn{3}{|c|}{ Intra-assay } & \multicolumn{3}{|c|}{ Inter-assay } \\
\hline & Mean & SD & CV (\%) & Mean & SD & $\mathrm{CV}(\%)$ \\
\hline $10^{10}$ & 7.0 & 0.30 & 4.3 & 6.9 & 0.34 & 4.9 \\
\hline $10^{9}$ & 9.9 & 0.19 & 1.8 & 10.1 & 0.23 & 2.3 \\
\hline $10^{8}$ & 13.4 & 0.25 & 1.9 & 13.6 & 0.34 & 2.5 \\
\hline $10^{7}$ & 16.9 & 0.29 & 1.7 & 17.0 & 0.36 & 2.1 \\
\hline $10^{6}$ & 20.8 & 0.33 & 1.6 & 20.9 & 0.40 & 1.9 \\
\hline $10^{5}$ & 24.7 & 0.37 & 1.5 & 24.7 & 0.49 & 2.0 \\
\hline $10^{4}$ & 28.6 & 0.49 & 1.7 & 28.7 & 0.77 & 2.7 \\
\hline $10^{3}$ & 32.3 & 0.52 & 1.6 & 32.2 & 0.90 & 2.8 \\
\hline $10^{2}$ & 35.4 & 0.81 & 2.3 & 35.3 & 1.16 & 3.3 \\
\hline 101 & 37.2 & 2.31 & 6.2 & 37.5 & 2.51 & 6.7 \\
\hline
\end{tabular}


demonstrated that the established fluorescent quantitative real-time PCR method was characterized by a wide dynamic range ( 8 logarithmic decades) of detection from $1.0 \times 10^{9}$ to $1.0 \times 10^{2} \mathrm{pAHV}-1$ plasmid copies $/ \mu \mathrm{L}$ with high precision. However, at lower and higher dilutions quantitation was not always reproducible compared to other properly diluted samples. Therefore the dynamic range of the method was between $1.0 \times 10^{9}$ and $1.0 \times 10^{2}$ pAHV-1 plasmid copies $/ \mu \mathrm{L}$, which is relatively broad.

\section{Test of established AHV-I FQ-PCR assay using specimens for practical applications}

Viral load quantification through the established AHV-1 FQ-PCR demonstrated that the AHV-1 DNA copy number of each sample could be calculated with the CT value according to the standard curve and $100 \%$ of the samples tested were quantifiable (Table 2) without the need for further sample dilution or concentration.

\section{Discussion}

Conventional etiological, immunohistological and serological methods [18-20] were routinely used in AHV-1 identification. However, the sensitivity is usually not high enough and the methods were time-consuming since virus propagation in cell cultures is usually required and the onset of virus-induced cytopathic effect (CPE) usually requires at least 2-3 days to develop. Titration of infectious virus in cell cultures is usually achieved by the endpoint dilution method in cell monolayer. Since titration of the virus load is labor-consuming and requires about 5 days for evaluation of virus-induced CPE, distinguishing between virus-induced CPE and non-specific cell alterations may be difficult, the established real-time PCR assay will be particularly suitable in these studies. In addition, an even more important factor is that the virus from tissues of infected birds is usually not readily adapted to cell

Table 2: AHV-I viral load in different clinical samples

\begin{tabular}{lc}
\hline Sample name & DNA amounts (copies) \\
\hline DEF cell culture supernatant & $5.67 \times 10^{6} / \mu \mathrm{L}$ \\
DEF cell culture & $1.05 \times 10^{9} / \mu \mathrm{L}$ \\
Allantoid fluid & $2.85 \times 10^{6} / \mu \mathrm{L}$ \\
Liver & $2.73 \times 10^{9} / \mathrm{g}$ \\
Brain & $2.20 \times 10^{7} / \mathrm{g}$ \\
Bursa of Fabricius & $9.47 \times 10^{9} / \mathrm{g}$ \\
Thymus & $1.09 \times 10^{9} / \mathrm{g}$ \\
Spleen & $3.59 \times 10^{9} / \mathrm{g}$ \\
Esophagus & $9.56 \times 10^{9} / \mathrm{g}$ \\
Duodenum & $3.92 \times 10^{7} / \mathrm{g}$ \\
Ileum & $1.83 \times 10^{8} / \mathrm{g}$ \\
Kidney & $1.78 \times 10^{8} / \mathrm{g}$ \\
Lung & $3.15 \times 10^{8} / \mathrm{g}$ \\
Peripheral blood & $2.16 \times 10^{6} / \mu \mathrm{L}$ \\
Cloacal swab & $2.11 \times 10^{8} / \mathrm{swab}$ \\
Oral swab & $2.83 \times 10^{8} / \mathrm{swab}$ \\
\end{tabular}

culture system during the initial several rounds of propagations [21].

The PCR is a rapid, sensitive and specific nucleic acid amplification technique and many conventional qualitative PCR methods for revealing merely the presence or absence of AHV-1 pathogen have been developed and well documented [22-24]. However, the conventional PCR assays are not sufficient in a variety of clinical situations. They frequently encountered problems including the risk of cross-contamination (leading to false positives) and poor quality of extracts (leading to false negatives). Moreover, the lack of fluorogenic probes in the assay results in relative lower specificity since the amplification and detection of specific PCR products are determined solely by the amplification primers. In this paper, the development of a TaqMan MGB-based real-time PCR by using fluorogenic labels and sensitive signal detection system for detection and quantitation of AHV-1 is described. The optimized FQ-PCR detection system presented in this paper has been designed to address these issues and make it even more applicable for routine diagnostic use with several advantages over conventional PCR.

In this assay, the primers and probes have been selected on conserved DNA segments of AHV-1 genome. TaqMan Minor Groove Binding $\left(\mathrm{MGB}^{\mathrm{TM}}\right)$ probes as target-specific hydrolysis oligonucleotide employed in this assay are characterized by the conjugation of minor groove binders which increases the Tm of the hybridized probe and facilitates highly specific binding to the targeted sequence [25]. Moreover this probe contains a quencher dye that does not emit fluorescence within the detectable wavelength range and results in greater accuracy in the measurement. This improvement eliminates spectral overlaps with fluorescence emitted by the reporter dye, and results in greater accuracy in the measurement of reporter-specific signals.

In view of the great sensitivity of PCR, the occurrence of false negative results is a highly underestimated problem. So an artificial construct generated by cloning of the specific target sequence into a plasmid are often used as internal controls for the amplification step. This internal positive control was incorporated into the reaction system, thus improving diagnostic conclusions, especially negative results, which is most important in the light of quarantine programs.

By carrying out direct comparisons between the established FQ-PCR method and the conventional PCR method for AHV-1 detection, the results clearly showed that overall the established FQ-PCR detection method is more sensitive and reliable when compared to conventional gel-based PCR, since it was able to detect as few as 
$1.0 \times 10^{1}$ DNA copies of template. Furthermore, this established AHV-1 FQ-PCR method shows more excellent characteristics such as dynamic range (from $1.0 \times 10^{9}$ to $1.0 \times 10^{2} \mathrm{pAHV}-1$ plasmid copies $/ \mu \mathrm{L}$, which is approximately $10^{3}$ times broader) and sensitivity (detecting pAHV-1 plasmid down to dilutions of $1.0 \times 10^{1}$ copies $/ \mu \mathrm{L}$, which is about 2.3 times more sensitive) than other reported method [17].

The high quality hot start Taq DNA polymerase used in this assay could minimize unspecific amplifications and increase the PCR cycling efficiency. In addition, FQ-PCR reaction and detection is all done in a closed-tube system, the need for post-amplification manipulation is removed since the detection of the PCR products occurs online during real-time PCR amplification, hence greatly reducing the risk of cross-contamination and false positive results. The optimization of the AHV-1 FQ-PCR assay was focused on the concentration of primers and probe and $\mathrm{Mg}^{2+}$. When all these different practical refinements are combined, the final result is a molecular diagnostic method that is not only rapid and reliable, but one that is also easy to perform and applicable to use for testing large numbers of samples since the FQ-PCR presented the benefits of increased speed due to reduced cycle time and remove of post-amplification process, offering considerable labor savings and allowing higher throughput analysis than conventional PCR assays and thus is favorable for the transition of this method from research to routine use in laboratories. This method was preliminarily mentioned in a short report [26] but related details of primers and probe sequence, specificity test, sensitivity test, reproducibility analysis, dynamic range and internal control were unavailable. By contrast, great modification and optimization have been made in this paper to improve the quality of this study.

The AHV-1 FQ-PCR assay was highly reproducible and linear over a range of eight orders of magnitude from $10^{2}$ to $10^{9}$ copies, allowing a precise calculation of viral DNA load in samples containing a wide range of viral DNA amounts, eliminating the need for sample dilution and minimizing sample handling. The results for intra- and inter-assay precision indicate that both intra-assay and inter-assay CVs were satisfactorily low and the assay is reproducible, even between different batches of reagents used. Probability rather than sample quality variation is the predominant cause of variability at low copy numbers [27].

\section{Conclusion}

In conclusion, the FQ-PCR developed in this study is highly specific and sensitive with better parameters than conventional PCR method and is a valuable method for the detection of AHV-1. The method described in this study is especially helpful for high throughput analysis such as evaluating the efficacy of antiviral drugs and experimental vaccines for AHV-1. The research group of authors is currently using this technique to study the AHV1 distribution characteristics in vaccinated birds and in artificially infected birds. We believe that this method could expedite related AHV-1 research in the AHV-1 viral molecular biology.

\section{Methods \\ Cell, virus and PCR template DNA preparation}

Duck embryo fibroblast (DEF) monolayer was incubated at $37^{\circ} \mathrm{C}$ with $5 \% \mathrm{CO}_{2}$ in tissue culture flasks with Minimal Essential Medium (MEM) that contained 10\% fetal bovine serum (FBS), $100 \mathrm{U} / \mathrm{mL}$ penicillin, and $100 \mu \mathrm{g} / \mathrm{mL}$ streptomycin.

Anatid herpesvirus 1 (AHV-1, CHv virulent strain) was obtained from the Avian Disease Research Center of Sichuan Agricultural University (Yaan, Sichuan, China). Virus stock was added onto the surface of the cell layer which was about $90 \%$ confluency at time of infection and the maximum virus titers could usually be obtained $48 \mathrm{~h}$ postinfection.

Table 3: Oligonucleotide sequences of primers and probes used in AHV-I FQ-PCR detection

\begin{tabular}{llllll}
\hline Name & Type & Sequences (5'to 3') & Length (nt) & Position & Amplicon size (bp) \\
\hline Real-Fa & Forward & ttttcctcctcctcgctgagt & 21 & $357-377$ & 60 \\
Real-Pa & Probe & ccctgggtacaagcgc & 16 & $383-398$ & \\
Real-Ra & Reverse & ggccgggtttgcagaagt & 18 & $399-416$ & 498 \\
Con-Fb & Forward & ggacagcgtaccacagataa & 20 & $246-265$ & 92 \\
Con-R & Reverse & acaaatcccaagcgtag & 17 & $727-743$ & $1054-1070$ \\
IC-Fc & Forward & acgagcgcaacccttga & 17 & $1103-1125$ & \\
IC-Pc & Probe & cggtttgtcaccggcagtcacct & 23 & $1127-1145$ & \\
IC-Rc & Reverse & acgtcatccccaccttact & 19 & & \\
\hline
\end{tabular}

a Based on the nucleotide sequence AF064639.

b Based on the nucleotide sequence AF064639.

c Based on the nucleotide sequence AJ971894. 
DNA extraction from AHV-1 infected DEF cells and tissues of AHV-1 infected ducks were performed by using TIANamp Genomic DNA extracting kit (Tiangen Corporation, Beijing, China) according to the manufacture's instructions.

\section{PCR primers and probe design}

The FQ-PCR assay primers and probe (named Real-F, Real-R and Real-P respectively) design was carried out using the Primer Express ${ }^{\mathrm{TM}}$ software supplied by Applied Biosystems and their sequences were listed in Table 3. The forward and reverse primers amplified a 60 bp fragment of AHV-1 DNA polymerase gene as described (GenBank Accession No. AF064639). The fluorogenic probe was labelled at $5^{\prime}$ with FAM (6-carboxyfluorescein) dye as reporter and labelled at 3' with TAMRA (tetra-methylcarboxyrhodamine) as quencher and 3 'with $\mathrm{MGB}^{\mathrm{TM}}$ (Minor Groove Binder).

The conventional PCR amplification was carried out using primers designed using the Primer Premier ${ }^{\mathrm{TM}}$ software according to the sequence as described (GenBank Accession No. AF064639). The forward primer and reverse primer (named Con-F and Con-R respectively) sequences were listed in Table 3 and this primer pair yielded a 498 bp amplicon, in which the $60 \mathrm{bp}$ FQ-PCR fragment was nested.

All probes and primers were synthesized by Genecore Corporation (Shanghai, China) and purified by corresponding HPLC system.

\section{Development and optimization of fluorescent quantitative real-time $P C R$ and conventional PCR}

The real-time PCR was carried out using the ABI AmpliTaq Gold DNA polymerase system with an icycler IQ Realtime PCR Detection System (Bio-Rad Corp., Hercules, CA) according to the manufacturer's instructions. The reaction, data acquisition and analysis were performed using iCycler IQ optical system software. The Real-time PCR was performed in an $25 \mu \mathrm{L}$ reaction mixture containing $1 \times$ PCR buffer, $0.2 \mathrm{mmol} / \mathrm{L}$ dNTPs, $1 \mathrm{U}$ Taq and $1 \mu \mathrm{L}$ DNA template according to the manufacture's instructions. Autoclaved nanopure water was added to bring the final volume to $25 \mu \mathrm{L}$. The two-step PCR cycling condition was as follows: initial denaturation and hot-start Taq DNA polymerase activation at $95^{\circ} \mathrm{C}$ for $10 \mathrm{~min}, 50$ cycles of denaturation at $94^{\circ} \mathrm{C}$ for $15 \mathrm{~s}$, primer annealing and extension at $60^{\circ} \mathrm{C}$ for $20 \mathrm{~s}$ with fluorescence acquisition during each annealing and extension stage. Real-time PCR reactions were optimized in triplicate based on primer, probe and $\mathrm{MgCl}_{2}$ concentration selection criteria, which was performed according to $4 \times 4 \times 4$ matrix of primer concentrations $(0.2,0.3,0.4$ and $0.5 \mu \mathrm{mol} / \mathrm{L})$, probe con- centrations $(0.05,0.1,0.2$, and $0.3 \mu \mathrm{mol} / \mathrm{L})$ and $\mathrm{MgCl}_{2}$ concentrations $(2,4,6$ and $8 \mathrm{mmol} / \mathrm{L})$.

The conventional PCR was performed and optimized on a Mycycler ${ }^{\mathrm{TM}}$ thermo cycler system (Bio-Rad Corp., Hercules, CA, USA) with a $50 \mu \mathrm{L}$ PCR reaction system containing $1 \times$ PCR buffer, $0.2 \mathrm{mmol} / \mathrm{L}$ dNTPs mixture, $1.25 \mathrm{U}$ rTaq (Takara Bio Inc., Shiga, Japan), $0.5 \mu \mathrm{mol} / \mathrm{L}$ each forward and reverse primers and $1 \mu \mathrm{L}$ template DNA. All PCR experiments were carried out in $0.2 \mathrm{ml}$ thin-walled tubes with the following cycle parameters: The mixture was subjected to initial denaturation at $95^{\circ} \mathrm{C}$ for $1 \mathrm{~min}$, followed by 50 cycles of $95^{\circ} \mathrm{C}$ for $60 \mathrm{~s}$, annealing for $60 \mathrm{~s}$, extension at $72^{\circ} \mathrm{C}$ for $60 \mathrm{~s}$, and one cycle of final extension at $72^{\circ} \mathrm{C}$ for $5 \mathrm{~min}$. The amplified $498 \mathrm{bp}$ product then underwent electrophoresis on $1.0 \%$ agarose gels. Electrophoresis was carried out at $100 \mathrm{~V}$ in a Mini-sub (Bio-Rad Corp., Hercules, CA, USA) gel electrophoresis unit and gels were viewed under a UV transilluminator. The conventional PCR reactions were optimized based on $\mathrm{MgCl}_{2}$ concentration and annealing temperature selection criteria in a similar way as that of Real-time PCR and the selection was made by the brightness of the amplified $498 \mathrm{bp}$ fragments on the agarose gel under a UV transilluminator.

An internal positive control was introduced into the FQPCR assay to verify the absence of DNA losses during the extraction step and of PCR inhibitors in the DNA templates. The internal positive control of pGM-T recombinant vector (designed as $\mathrm{pB} 16 \mathrm{~S}$ ) consisting of Bacillus 16S rRNA gene (GenBank Accession No. AJ971894) sequence amplified with primers (IC-F and IC-R) listed in Table 3 was added into the lysis buffer at the concentration of $1.0 \times 10^{6} \mathrm{copies} / \mu \mathrm{L}$. Real-time PCR for IC detection was carried out in a separate run, using primers and probe (named IC-F, IC-R and IC-P respectively) listed in Table 3. The fluorogenic probe was labelled at $5^{\prime}$ with FAM as reporter and labelled at 3 ' with TAMRA. The quantitative real-time PCR protocol was the same as that of AHV-1 detection. From the ratio of the calculated amount of IC to the actual amount of IC, which is shared by the specimen, the normalization could be achieved and the actual amount of AHV-1 in the specimen could be obtained. Actually this internally controlled method has been widely used in other related detection assays $[28,29]$.

\section{Fluorescent quantitative real-time PCR standard curve establishment}

The 498 bp conventional PCR target amplicon band on agarose gel was cut and the DNA was recovered and purified by TIANquick DNA Purification system (Tiangen Corp., Beijing, China) according to the instruction manual of the product. The product was ligated into pGM-T vector (Tiangen Corp., Beijing, China) and transformed into E.coli DH5 $\alpha$ competent cells. Recombinant plasmid 
(designated as pAHV-1) was extracted using TIANprep plasmid extraction kit (Tiangen Corp., Beijing, China). Presence of the target DNA insert was confirmed by PCR amplification and sequencing.

The standard curve of the FQ-PCR was generated by successive dilutions of the known copy number of pAHV-1. Recombinant plasmid pAHV-1 concentration was determined by taking the absorbance at $260 \mathrm{~nm}$ using a Smartspec 3000 spectrophotometer (Bio-Rad Corp., Hercules, CA) and purity was confirmed using the 260/280 nm ratio. Through its molecular weight, pAHV-1 copy number was then calculated and the purified pAHV-1 plasmid DNA was then serially diluted 10 -fold in TE buffer, pH 8.0, from $1.0 \times 10^{9}$ to $1.0 \times 10^{2}$ plasmid copies/ $\mu \mathrm{L}$. These dilutions were tested in triplicate and used as quantitation standards to construct the standard curve by plotting the plasmid copy number logarithm against the measured CT values. The Bio-Rad iCycler IQ detection software created the standard curve, calculated the correlation coefficient $\left(\mathrm{R}^{2}\right)$ of the standard curve, standard deviations of triplicates.

\section{FQ-PCR sensitivity, specificity, reproducibility and dynamic range analysis}

Different 32 AHV-1 strains (derived from a wide spectrum of sources, subsequently confirmed through related etiological methods, and then preserved by the Avian Disease Research Center of Sichuan Agricultural University) including virulent and avirulent strains were examined with the established FQ-PCR method to test the sensitivity and compatibility of this method. In addition, the sensitivities of the conventional PCR and FQ-PCR were each determined using triplicates of different concentrations of recombinant plasmid pAHV-1. Template DNA was prepared as follows: plasmids of pAHV-1 were diluted serially in 10 -fold steps from $10^{10}$ copies $/ \mu \mathrm{L}$ to $10^{1}$ copies $/ \mu \mathrm{L}$ using sterile ultra pure water. One microliter from each dilution was used as template and subjected to the conventional PCR and FQ-PCR protocol respectively. The detection limit of the conventional PCR was determined based on the highest dilution that resulted in the presence of clear and distinct amplified fragments (498 bp) on the agarose gel. The detection limit of the FQ-PCR was determined based on the highest dilution that resulted in the presence of CT value in real-time PCR detection.

DNA from duck embryo fibroblast (DEF) and several other pathogens including duck hepatitis B virus, Salmonella enteritidis, duck adenovirus, goose parvovirus, Marek's disease virus, infectious laryngotracheitis virus and Pasteurella multocida (kindly provided by Avian Diseases Research Center of Sichuan Agricultural University) were used as templates in triplicates to confirm the technique's specificity.
Within-run and between-run reproducibilities of the FQPCR assay were assessed by multiple measurements of pAHV-1 samples of different concentrations. The assay was conducted by assessing the agreement between the replicates in five replicates (within-run precision) and in five separate experiments (between-run precision) of the serially diluted pAHV-1 recombinant plasmid samples through performing analysis of the mean coefficient of variation $(\mathrm{CV})$ values of each $\mathrm{AHV}-1$ standard dilution.

Dilutions of pAHV-1 recombinant plasmid were used to determine the dynamic ranges of the FQ-PCR assay. The lower and upper limits of quantification were defined by the pAHV-1 recombinant plasmid sample concentrations possessing reasonable precision.

\section{Test of established AHV-I FQ-PCR assay using specimens for practical applications}

AHV-1 infected duck embryo fibroblast culture, allantoid fluid and other specimens including liver, brain, Bursa of Fabricius, thymus, spleen, esophagus, duodenum, ileum, kidney, lung, peripheral blood each collected from AHV1 infected ducks were employed to assess the ability of the established FQ-PCR to detect AHV-1 in a variety of usually used samples. By this assay viral load quantification was obtained.

\section{Competing interests}

The authors declare that they have no competing interests.

\section{Authors' contributions}

YG carried out most of the experiments and wrote the manuscript. AC and MW critically revised the manuscript and the experiment design. CS, RJ, SC and NZ helped with the experiment. All of the authors read and approved the final version of the manuscript.

\section{Acknowledgements}

This project was funded by a grant from the National Natural Science Foundation of China (grant No. 30771598), the Cultivation Fund of the Key Scientific and Technical Innovation Project, department of Education of Sichuan Province (grant no. 07ZZ028), China Postdoctoral Science Foundation (grant No. 20060391027), Program for Changjiang Scholars and Innovative Research Team in University (grant No. IRT0848), Scientific and Technological Innovation Major Project Funds in University (grant No. 706050), the earmarked fund for Modern Agro-industry Technology Research System (nycytx-45-12) and Sichuan Province Basic Research Program (grant No. 07JY029-016/07JY029-0 I7/2008JO0003/2008JY0 I00/ 2008jY0 102). The authors wish to thank our colleagues for their professional assistance and technical support to this study.

\section{References}

I. Sluis W: Ducks are a flavour for the future. World Pou 2004, 20:4l.

2. Sandhu TS, Shawky SA: Duck virus enteritis (Duck plague). In Diseases of Poultry I I th edition. Edited by: Saif YM, Barnes HJ, Glisson JR. lowa State Press, Ames; 2003:354-363. 
3. Montgomery RD, Stein G Jr, Novilla MN, Hurley SS, Fink RJ: An outbreak of duck virus enteritis (duck plague) in a captive flock of mixed waterfowl. Avian Dis 198I, 25:207-213.

4. Brand C], Docherty DE: A survey of north American migratory waterfowl for duck plague (duck virus enteritis) virus. J Wildl Dis 1984, 20:261-266.

5. Brand C], Docherty DE: Post-epizootic surveys of waterfowl for duck plague (duck virus enteritis). Avian Dis 1988, 32:722-730.

6. Burgess EC, Ossa J, Yuill TM: Duck plague: a carrier state in waterfowl. Avian Dis 1979, 24:940-949.

7. Kaleta EF: Herpesviruses of birds. Avian Pathol 1990, 19:193-211.

8. Fukuchi K, Sudo M, Lee YS, Tanaka A, Nonoyama M: Structure of Marek's disease virus DNA: detailed restriction map. J Virol 1984, 5 I: 102-109.

9. Gardner R, Wilkerson J, Johnson JC: Molecular characterization of the DNA of anatid herpesvirus I. Intervirology 1993, 36:99-1I2.

10. Chen RW, Piiparinen H, Seppänen M, Koskela P, Sarna S, Lappalainen M: Real-time PCR for detection and quantitation of hepatitis B virus DNA. J Med Virol 200I, 65:250-256.

II. Jebbink J, Bai X, Rogers BB, Dawson DB, Scheuermann RH, DomiatiSaad R: Development of real-time PCR assays for the quantitative detection of Epstein-Barr virus and cytomegalovirus, comparison of TaqMan probes, and molecular beacons. J Mol Diagn 2003, 5: 15-20.

12. Weinberger KM, Wiedenmnm E, Böhm S, Jilg W: Sensitive and accurate quantitation of hepatitis $B$ virus DNA using a kinetic fluorescence detection system (TaqMan PCR). J Virol Methods. 2000, 85( I-2):75-82.

13. Watzinger F, Suda M, Preuner S, Baumgartinger R, Ebner K, Baskova L, Niesters HG, Lawitschka A, Lion T: Real-time quantitative PCR assays for detection and monitoring of pathogenic human viruses in immunosuppressed pediatric patients. Clin Microbiol 2004, 42:5189-5198.

14. Humar A, Kumar D, Boivin G, Caliendo AM: Cytomegalovirus (CMV) virus load kinetics to predict recurrent disease in solid-organ transplant patients with CMV disease. J Infect Dis 2002, 186:829-833.

15. Häusler M, Scheithauer S, Ritter K, Kleines M: Molecular diagnosis of Epstein-Barr virus. Expert Rev Mol Diagn 2003, 3:8I-92.

16. Watzinger F, Ebner K, Lion T: Detection and monitoring of virus infections by real-time PCR. Mol Aspects Med 2006, 27:254-298.

17. Yang F, Jia W, Yue H, Luo W, Chen X, Xie Y, Zen W, Yang W: Development of quantitative real-time polymerase chain reaction for duck enteritis virus DNA. Avian Dis 2005, 49:397-400.

18. Salguero FJ, Sánchez-Cordón PJ, Núñez A, Gómez-Villamandos JC: Histopathological and ultrastructural changes associated with herpesvirus infection in waterfowl. Avian Pathol 2002, 31:133-140.

19. Islam MR, Nessa J, Halder KM: Detection of duck plague virus antigen in tissues by immunoperoxidase staining. Avian Pathol 1993, 22:389-393.

20. Wolf K, Burke CN, Quimby MC: Duck viral enteritis: microtiter plate isolation and neutralization test using the duck embryo fibroblast cell line. Avian Dis 1974, 18:427-434.

21. Guo Y, Cheng A, Wang M, Jia R, Wen M, Zhou W, Chen X: Studies on the growth characteristics of duck enteritis virus $\mathrm{CH}$ virulent strain on duck embryo fibroblast. Poult Husb dis control 2007, 4:2-4.

22. Hansen WR, Brown SE, Nashold SW, Knudson DL: Identification of duck plague virus by polymerase chain reaction. Avian Dis 1999, 43(1): 106-115.

23. Plummer PJ, Alefantis T, Kaplan S, O'Connell P, Shawky S, Schat KA Detection of duck enteritis virus by polymerase chain reaction. Avian Dis 1998, 42:554-564.

24. Pritchard LI, Morrissy C, Phuc KV, Daniels PW, Westbury HA Development of a polymerase chain reaction to detect Vietnamese isolates of duck virus enteritis. Vet Microbiol 1999, 68:149-156.

25. Kutyavin IV, Afonina IA, Mills A, Gorn VV, Lukhtanov EA, Belousov ES, Singer MJ, Walburger DK, Lokhov SG, Gall AA, Dempcy R, Reed MW, Meyer RB, Hedgpeth J: 3'-minor groove binder-DNA probes increase sequence specificity at PCR extension temperatures. Nucleic Acids Res 2000, 28:655-66I.
26. Guo Y, Cheng A, Wang M, Jia R, Wen M, Zhou W, Chen X: Establishment and application of quantitative real-time $P C R$ assay for detecting duck viral enteritis virus. Vet Sci chin 2006, 36:444-448

27. De Vries TJ, Fourkour A, Punt CJA, Locht LTF van de, Wobbes T, Bosch S van den, de Rooij MJM, Mensink EJBM, Ruiter DJ, van Muijen GNP: Reproducibility of detection of tyrosine and MART-I transcripts in the peripheral blood of melanoma patients: a quality control study using real-time quantitative RT-PCR. Br J Cancer 1999, 80:883-89|.

28. Decaro N, Elia G, Campolo M, Desario C, Mari V, Radogna A, Colaianni ML, Cirone F, Tempesta M, Buonavoglia C: Detection of bovine coronavirus using a TaqMan-based real-time RT-PCR assay. J Virol Methods. 2008, I I I(2):167-I7I.

29. Elia G, Tarsitano E, Camero M, Bellacicco AL, Buonavoglia D, Campolo M, Decaro N, Thiry J, Tempesta M: Development of a realtime PCR for the detection and quantitation of caprine herpesvirus I in goats. J Virol Methods. 2008, I48(I-2): I55-I60.
Publish with Biomed Central and every scientist can read your work free of charge

"BioMed Central will be the most significant development for disseminating the results of biomedical research in our lifetime. "

Sir Paul Nurse, Cancer Research UK

Your research papers will be:

- available free of charge to the entire biomedical community

- peer reviewed and published immediately upon acceptance

- cited in PubMed and archived on PubMed Central

- yours - you keep the copyright
BioMedcentral 